\title{
A simple apparatus for sampling sea surface microlayers
}

\author{
Lydia Ignatiades
}

Nuclear Research Center Democritos, Aghia Paraskevi Attikis, Athens, Greece

ABSTRACT: A simple and inexpensive apparatus for sampling the upper $3 \mathrm{~mm}$ of sea surface microlayers is described. It is constructed from plexiglass and is quick in operation and suitable for studies of the microlayer ecosystem.

In the vertical dimension, the term surface microlayer' of seawater refers to a depth scale ranging from $<1 \mathrm{~mm}$ to a few centimeters (Parker 1978, Hardy 1982).

Surface microlayers of the marine environment tend to concentrate phytoplankton populations (phytoneuston) with abundance, pigment composition, photosynthetic activity, taxonomic diversity and dominance different to underlying communities (Harvey 1966, 1974, Roy et al. 1970, Marumo et al. 1971, Hardy 1973, 1982, Gallagher 1975, Manzi et al. 1977, Wandschneider 1979, Hardy \& Apts 1984).

Assessing the overall behaviour of phytoplankton in surface microlayers requires the use of a collection device quick in operation and effective in providing sufficient water from a large enough surface area for a statistically reliable population sample (Wangersky 1976). The most commonly used samplers (Garrett 1965, Harvey 1966) do not fulfill these criteria because they either do not collect large enough samples or require a great deal of sampling time to do so (Wangersky 1976).

This paper describes a simple device for continuous sampling of sea surface microlayers of $3 \mathrm{~mm}$ thickness. Sample thickness for this equipment is larger than for Garrett's (1965) screen collector (100 to $250 \mu \mathrm{m})$ but thinner than for the box collector $(4 \mathrm{~mm})$ designed by Hardy (1973).

The sampler consists of 2 square plexiglass plates of $45 \mathrm{~cm}^{2}$ surface area and $4 \mathrm{~cm}$ thickness, cemented to make a box (water collector) with $3 \mathrm{~mm}$ inside height (Fig. 1). One side of the box is left open (inlet opening) to form a 'window' of $44 \mathrm{~cm} \times 44 \mathrm{~cm} \times 3 \mathrm{~mm}$ inside dimensions. The upper plate has a hole of $4.0 \mathrm{~mm}$ diameter (outlet opening) in the center, which is connected by a rubber tube ( $4 \mathrm{~m}$ long) to a $5 \mathrm{l}$ vacuum flask. The under-surface of the box is supported by

Fig. 1. The sampler. A: hand pump; B: vacuum flask; C: water collector. Arrows indicate water movement via the water collector and rubber tubing to the vacuum flask

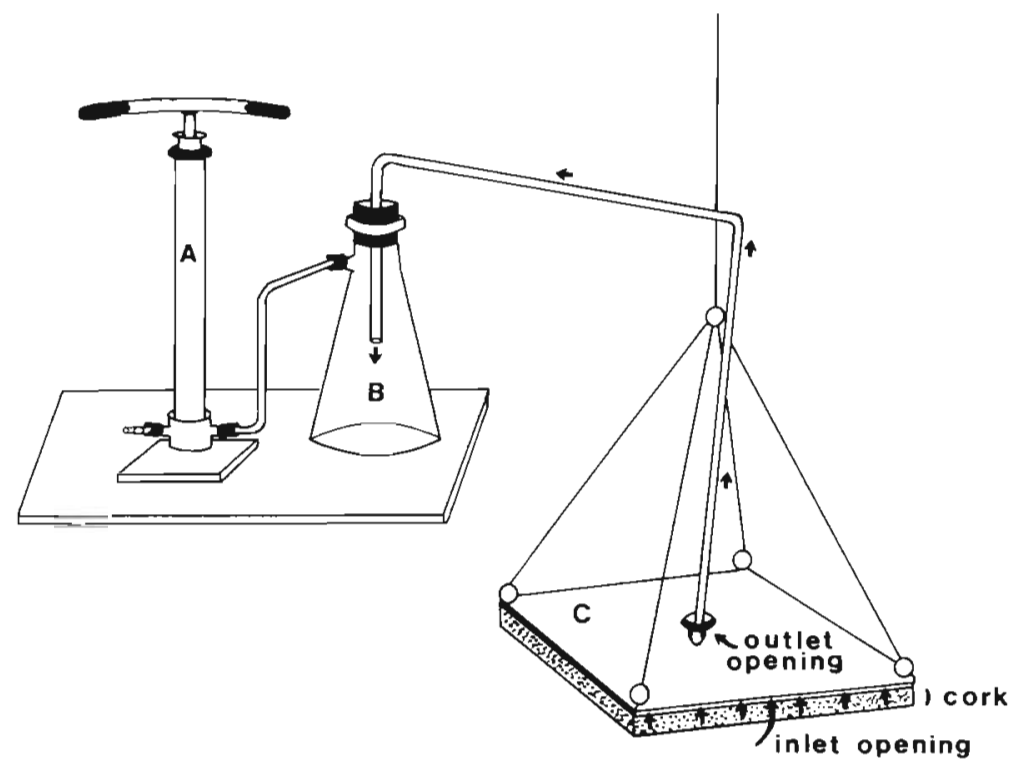


cork of $1 \mathrm{~cm}$ thickness to provide sufficient buoyancy so that the box floats with its inlet opening just covered by the upper $3 \mathrm{~mm}$ of water. The box can be lifted by wires attached to its 4 corners.

When the sampler is allowed to float on the sea it is immediately filled with water from the upper $3 \mathrm{~mm}$ layer through its inlet opening. A hand pump empties the air from the vacuum flask and water from the sampler is sucked continuously via the outlet opening and the rubber tubing into the flask. Slow horizontal translocation of the device allows sampling from a large area.

Advantages of the sampler are: (1) It is inexpensive, light in weight and simple in operation; (2) It is capable of continuous and relatively uniform sampling of sufficient water from a large surface area, and thus suitable for studies of the microlayer ecosystem.

\section{LITERATURE CITED}

Gallagher, J. L. (1975). The significance of the surface film in salt marsh plankton metabolism. Limnol. Oceanogr. 20: 120-123

Garrett, W. D. (1965). Collection of slick-forming materials from the sea surface. Limnol. Oceanogr. 10: 602-605
Hardy, T J. (1973). Phytoneuston ecology of a temperate marine lagoon. Limnol. Oceanogr. 18: 525-533

Hardy, T J. (1982). The sea surface microlayer: biology, chemistry and anthropogenic enrichment. Prog. Oceanogr. 11: 307-328

Hardy, T. J., Apts, C. W. (1984). The sea surface microlayer phytoneuston productivity and effects of atmospheric particulate matter. Mar. Biol. 82: 293-300

Harvey, G. W. (1966). Microlayer collection from the sea surface: a new method and initial results. Limnol Oceanogr. 11: 608-613

Harvey, G. W. (1974). The microlayer ecosystem at the air-sea interface. Abstracts of contributed papers. Limnol Oceanogr. 19: 162-165

Manzi, J. J., Stofan, P. E., Dupuy, J. L. (1977). Spacial heterogeneity of phytoplankton populations in estuarine microlayers. Mar. Biol. 41: 29-38

Marumo, T., Taga, N., Nakai, T. (1971). Neustonic bacteria and phytoplankton in surface microlayers of the equatorial waters. Bull. Plankton Soc. Japan 18: 36-41

Parker, B. C. (1978). Neuston sampling. In: Sournia, A. (ed.) Phytoplankton manual. UNESCO Monogr. Oceanogr. Methodol. Vol. 6, p. 64-67

Roy, V. M., Dupuy, J. L., MacIntyre, W. G., Harrison, W (1970). Abundance of marine phytoplankton in surface films. Proc. Symp. Hydrobiol. Am. Wat. Resour. Ass. Urbana, lllinois 8: 371-380

Wandschneider, K. (1979). Vertical distribution of phytoplankton during investigations of a natural surface film. Mar. Biol. 52: 105-112

Wangersky, P. J. (1976). The surface film as a physical environment. A. Rev. Ecol. Syst. 7: 161-176 